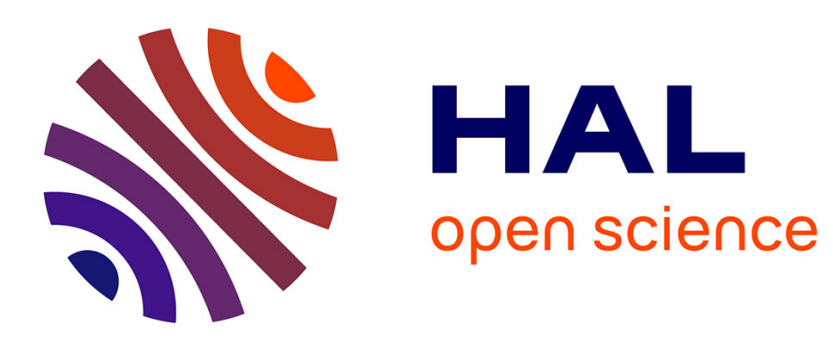

\title{
Unemployment and Firm Entry and Exit: An Update on a Controversial Relationship
}

Enrico Santarelli, Martin Carree, Ingrid Verheul

\section{To cite this version:}

Enrico Santarelli, Martin Carree, Ingrid Verheul. Unemployment and Firm Entry and Exit: An Update on a Controversial Relationship. Regional Studies, 2009, 43 (08), pp.1061-1073. 10.1080/00343400801968361 . hal-00516203

\section{HAL Id: hal-00516203 https://hal.science/hal-00516203}

Submitted on 9 Sep 2010

HAL is a multi-disciplinary open access archive for the deposit and dissemination of scientific research documents, whether they are published or not. The documents may come from teaching and research institutions in France or abroad, or from public or private research centers.
L'archive ouverte pluridisciplinaire HAL, est destinée au dépôt et à la diffusion de documents scientifiques de niveau recherche, publiés ou non, émanant des établissements d'enseignement et de recherche français ou étrangers, des laboratoires publics ou privés. 


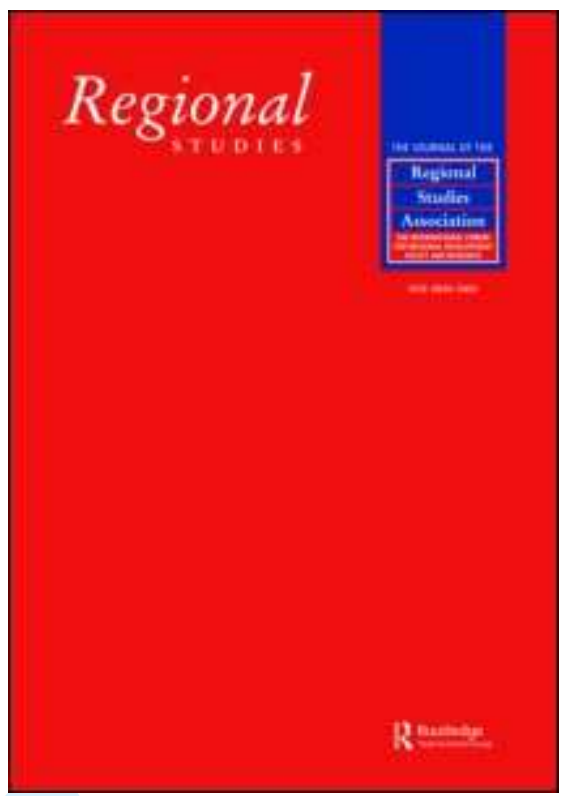

\section{Unemployment and Firm Entry and Exit: An Update on a Controversial Relationship}

\begin{tabular}{|r|l|}
\hline Journal: & Regional Studies \\
\hline Manuscript ID: & CRES-2006-0128.R3 \\
\hline Manuscript Type: & Main Section \\
\hline JEL codes: & $\begin{array}{l}\text { J60 - General < J6 - Mobility, Unemployment, and Vacancies < J - } \\
\text { Labor and Demographic Economics, R11 - Regional Economic } \\
\text { Regional Economics < R - Urban, Rural, and Regional Economics, } \\
\text { R23 - Regional Migration|Regional Labor Markets|Population }<\text { R2 - } \\
\text { Household Analysis < R - Urban, Rural, and Regional Economics }\end{array}$ \\
\hline \hline Keywords: & unemployment, firm entry and exit, Italian provinces \\
\hline
\end{tabular}

\section{SCHOLARONE" Manuscripts}




\title{
Unemployment and Firm Entry and Exit: An Update on a Controversial Relationship*
}

\author{
ENRICO SANTARELLI \\ University of Bologna \\ Department of Economics \\ Piazza Scaravilli, 2, I-40126 Bologna, Italy \\ Tel.: +39 512098487 / E-mail: enrico.santarelli@,unibo.it \\ and \\ Max Planck Institute of Economics \\ Entrepreneurship, Growth and Public Policy Group \\ Jena, Germany \\ MARTIN CARREE \\ Maastricht University \\ Faculty of Economics and Business Administration \\ P.O. Box 616, 6200 MD Maastricht, the Netherlands \\ Tel: +31 433884981 / E-mail: m.carree@os.unimaas.nl \\ INGRID VERHEUL \\ Erasmus University Rotterdam \\ Department of Applied Economics \\ Centre for Advanced Small Business Economics \\ P.O. Box 1738, 3000 DR Rotterdam, the Netherlands \\ Tel: +31 104081422 / E-mail: verheul@few.eur.nl
}

First received: June 2006

Accepted: November 2007

JEL codes: J60, R11, R23

Keywords: unemployment; firm entry and exit; Italian provinces

Abstract: The present study explores the relationship between unemployment and subsequent firm entry and exit for 103 Italian provinces for the period 1997 to 2003 . We estimate two models. In the first model we concentrate on unemployed individuals, starting or closing a business in the province they live in. In the second model we incorporate cross-border effects by taking into account possible start-ups by unemployed individuals from adjacent provinces. Findings show that a positive effect of unemployment on net entry is not due to a positive 'push' effect on entry but rather to a negative effect of unemployment on firm exit. This indicates a lack of dynamics in the Italian labor market. 
Le chômage et l'entrée et la sortie des entreprises:

une mise à jour d'un rapport controversé.

Santarelli et al.

La présente étude cherche à examiner le rapport entre le chômage et l'entrée et la sortie ultérieures des entreprises pour 103 provinces italiennes pendant la période allant de 1997 jusqu'à 2003. On estime deux modèles. Quant au premier modèle, on se concentre sur les chômeurs qui créent ou qui ferment une entreprise dans la province où ils habitent. Pour ce qui est du deuxième modèle, on y inclut des effets transfrontaliers, en tenant compte des créations d'entreprise éventuelles par les chômeurs qui habitent les provinces limitrophes. Il s'avère que l'effet positif du chômage sur l'entrée nette ne s'explique pas par un effet 'moteur' positif au moment de l'entrée mais plutôt par l'effet négatif du chômage sur la sortie des entreprises. Ceci indique un manque de dynamique sur le marché du travail italien.

Chômage / Entrée et sortie des entreprises / Provinces italiennes

Classement JEL: J60; R11; R23

\title{
Arbeitslosigkeit und Betriebsgründungen bzw. -schließungen: aktuelle Informationen zu einer kontroversen Beziehung
}

EnRICo SANTARELLI, MARTIN CARREe AND INGRID VERHEUL

JEL codes: J60, R11, R23

Keywords:

Arbeitslosigkeit

Betriebsgründungen und -schließungen

Italienische Provinzen

\begin{abstract}
:
In dieser Studie wird die Beziehung zwischen Arbeitslosigkeit und anschließenden Betriebsgründungen bzw. -schließungen in 103 italienischen Provinzen im Zeitraum von 1997 bis 2003 untersucht. Wir stellen Schätzungen anhand von zwei Modellen auf. Im ersten Modell konzentrieren wir uns auf arbeitslose Einzelpersonen, die in der Provinz, in der sie leben, einen Betrieb gründen oder schließen. Im zweiten Modell integrieren wir grenzübergreifende Auswirkungen, indem wir mögliche Neugründungen durch arbeitslose Einzelpersonen aus angrenzenden Provinzen berücksichtigen. Aus den Ergebnissen geht hervor, dass eine positive Auswirkung der Arbeitslosigkeit auf die Nettozahl der Firmengründungen nicht auf einen positiven 'Push'-Effekt auf die Betriebsgründungen zurückzuführen ist, sondern vielmehr auf einen negativen Effekt der Arbeitslosigkeit auf die Betriebsschließungen. Dies weist auf eine mangelnde Dynamik des italienischen Arbeitsmarkts hin.
\end{abstract}


Desempleo y entrada y salida de empresas: actualización de una relación controvertida

\title{
ENRICO SANTARELLI, MARTIN CARREE AND INGRID VERHEUL
}

\begin{abstract}
:
En el presente estudio analizamos la relación entre el desempleo y la posterior entrada y salida de empresas para 103 provincias italianas durante el periodo de 1997 a 2003. Evaluamos dos modelos. En el primer modelo nos centramos en personas desempleadas, que empiezan o cierran un negocio en la provincia en la que viven. En el segundo modelo incorporamos los efectos transfronterizos teniendo en cuenta posibles empresas emergentes por parte de personas en paro de provincias adyacentes. Los resultados indican que un efecto positivo del desempleo en la entrada neta no se debe a un efecto positivo de 'empuje' sino a un efecto negativo del desempleo al cerrar las empresas. Esto indica una falta de dinámica en el mercado laboral italiano.
\end{abstract}

Keywords:

Desempleo

Entrada y salida de empresas

Provincias italianas

JEL codes: J60, R11, R23 


\section{Enrico Santarelli, Martin Carree and Ingrid Verheul}

\section{INTRODUCTION}

Substantial variation in unemployment rates can exist between regions within one country. For example, in Belgium the unemployment rate in Wallonia is twice as high as that in Flanders; in Germany the unemployment rates in the eastern Länder are three times as high as those of Bayern and Baden-Württemberg; and in Italy the rates in the Southern provinces are about four times as high as those in the Northern provinces. Such regional inequalities in labor market conditions may persist for several decades. Governments can intervene to reduce these regional inequalities by subsidizing new economic activity in the poorer regional or local entities or by raising entrepreneurial skills in society as a whole and stimulating entrepreneurial awareness in young people. Such intervention may be particularly suitable for regions that combine a high level of unemployment with a low propensity to start new businesses.

The relationship between unemployment and new firm formation is of a complex nature. Regions with high unemployment rates may also be characterized by high firm birth rates. This can be explained by the so-called 'unemployment push' hypothesis stating that unemployed workers are more likely to become self-employed - as compared to employees because they are more likely to be dissatisfied with their current labor market position. EvANS and Leighton, 1990, provided empirical evidence for the United States and found that unemployed individuals were about twice as likely to start a new business than wageemployed individuals. On the regional level the evidence for the unemployment push hypothesis has been more mixed. CARREE, 2002, finds little evidence for an effect of the unemployment rate on net entry of new establishments in retail and consumer service industries in the United States. REYNOLDS et al., 1994, find that firm births per population is positively affected by the level of unemployment in France, Sweden and the United States; that there is no effect in Germany and the United Kingdom and a negative effect in Italy. 


\section{Enrico Santarelli, Martin Carree and Ingrid Verheul}

This study provides further insight into the unemployment push hypothesis by distinguishing between firm entry and exit rates and by taking into account unemployed individuals from adjacent provinces. We investigate the explanatory power of regional unemployment (next to other regional characteristics) when explaining venture creation and dissolution. By way of disentangling the effects of unemployment on entry and exit we are able to indicate the main mechanism (i.e., entry or exit) through which unemployment influences net entry. We take a regional economics perspective to explaining self-employment, focusing on market entry and exit, instead of a labor market perspective, focusing on the individual choice to become selfemployed (PFEIFFER and REIZE, 2000). We investigate the relationship between regional unemployment and firm entry and exit in Italy, a country that is characterized by considerable variation in unemployment rates across regions and traditionally high self-employment rates (cf. CARREE et al., 2002). We make use of new data covering firm births and deaths in the 103 Italian provinces for the period between 1997 and $2003^{1}$. This is an interesting period because there was a deregulation of entry in Italy ${ }^{2}$.

This article is structured as follows. In Section 2 we discuss existing literature on the relationship between unemployment and entrepreneurial activity. We pay attention to the different ways in which unemployment relates to firm entry including the 'unemployment push' hypothesis, the negative effect of unemployment on entrepreneurial activity and reversed causality. Section 3 gives an overview of firm birth, exit and unemployment rates in the Italian provinces and regions. Section 4 introduces the model and Section 5 presents and discusses the estimation results. Finally, Section 6 concludes, summarizing the main results in the paper.

\section{UNEMPLOYMENT AND NEW FIRM FORMATION}

The activities of individuals in the labor force can be divided into wage-employment, unemployment and self-employment. The vast majority of individuals falls exclusively into 


\section{Enrico Santarelli, Martin Carree and Ingrid Verheul}

one of these three categories instead of combining activities (e.g., part-time engagement in wage- and self-employment). KNIGHT, 1921, argued that individuals have to make a decision about how to allocate their time and abilities among these three different types of activity. This occupational decision is shaped by the respective costs and benefits of the activities. HAMiLton, 2000, shows that - next to earnings - the occupational decision is affected by non-pecuniary benefits. In general unemployment is perceived as the least desirable employment status. In this respect OXENFELDT, 1943, notes that individuals with low prospects of wage-employment tend to become self-employed. The link between unemployment and subsequent entry into self-employment has been referred to as the ‘unemployment push' hypothesis ${ }^{3}$.

There are two important counter-arguments to the 'unemployment push' hypothesis (CARREE, 2002). First, the 'push' effect in a region with a high unemployment rate may be diminished by the 'pull' effect of a low unemployment rate (CHOI and PHAN, 2006). Low levels of unemployment suggest economic strength and ample opportunities for new entrepreneurs. It may be difficult to capture negative depressed economy effects of unemployment (such as a decrease in consumer demand) in the analysis ${ }^{4}$. Second, on average the level of human and entrepreneurial capital of the unemployed may be lower than that of employed workers, inhibiting new firm creation by the unemployed. Indeed, ACs and ARMINGTON, 2004, report that in the United States areas with high levels of education are also characterized by high rates of new firm formation.

There may also be reversed causality where self-employment rates influence unemployment rates. ACS and STOREY, 2004, find "some evidence that geographical areas that experience a rise in new firm formation subsequently experience economic development" (p.873/4). Next to employing themselves, entrepreneurs also provide employment for others. There has been abundant evidence that small and new firms grow faster than their older and larger 


\section{Enrico Santarelli, Martin Carree and Ingrid Verheul}

counterparts (e.g., AUDRETSCH et al., 2004). CAMPBELL, 1996, argues that in a situation of unemployment, employment creation is enhanced as it is cheaper to hire new workers. This is important, in particular, for newly started enterprises that rely on labor rather than capital in their production process. Hence, while unemployment rates may stimulate the rate of selfemployment, higher entrepreneurial activity rates may in turn reduce unemployment in subsequent periods (AUDRETSCH et al., 2005). Again others argue there is a positive (short term) effect of entrepreneurial activity on unemployment. FRITSCH and MUELLER, 2004, claim that higher competition due to new firm entry in the short run leads to more firm exit and increased unemployment. In the long run increased competition will positively affect economic performance and employment. This argument relates to the Schumpeterian mechanism of creative destruction.

The above considerations show that the relation between unemployment and self-employment or new firm start-ups is complex. It is not surprising that there has been mixed empirical evidence on the relationship between unemployment and firm birth rates at the regional level. STOREY, 1991, reports on this mixed evidence and argues that there is a tendency for timeseries studies to find evidence for a positive relationship and for cross-sectional studies to support a reverse relationship. See also FotI and VIVARELLI, 1994, p. $83^{5}$. However, a recent time-series analysis by CHOI and PHAN, 2006, reveals no significant relationship for the United States. The mixed evidence on the relationship between unemployment and firm entry may also relate to the fact that existing studies use different indicators and are carried out for different industries, countries and geographical units of analysis. AUDRETSCH and FRITSCH, 1999, and CARREE, 2002, stress the importance of the industrial organization aspect. They find a positive effect of unemployment only for industries with (very) low barriers to entry. In general studies report a significant regional variation in new firm formation and identify various regional determinants to explain this variation (REYNOLDS et al., 1994) ${ }^{6}$. 


\section{Enrico Santarelli, Martin Carree and Ingrid Verheul}

Unemployment is often included as an explanatory variable. Regional studies that find evidence for a negative effect of unemployment on firm births include those by AUDRETSCH and Fritsch, 1994, DAVIDSSON et al., 1994, FritsCh and FAlCK, 2003, GAROFOLI, 1994, Guesnier, 1994, ReynOlds et al., 1995, Ritsilä and Tervo, 2002, SutARIA and Hicks, 2004. A positive effect is found, for example, by CAMPBELl, 1996, CARREE and THURIK, 1996, LEE et al., 2004, and TAMBUNAN, 1992; 1994.

The present study investigates effects of unemployment not only on gross entry, but also on gross exit and net entry rates. Unemployment may not only affect the rate of new entry of firms, but also of the extent to which firms exit. BUZzELLI, 2005, and LOVE, 1996, find that unemployment leads to higher exit rates. Hence, unemployment may be a proxy for lack of economic strength, producing higher mortality rates. We investigate whether this effect holds for Italy when correcting for a range of regional characteristics.

\section{UNEMPLOYMENT, ENTRY AND EXIT IN ITALY}

To test for the relationship between unemployment and firm entry and exit we use data on unemployment, entry and exit rates for all 103 provinces in Italy (Source: Unioncamere). ${ }^{7}$ Table 1 gives an overview of the lowest and highest provincial unemployment, entry and exit rates in Italy by presenting the top-15 and bottom-15 provinces in Italy. Unemployment is highest in the Southern part of Italy including provinces in the regions Calabria (i.e., Catanzaro, Reggio Calabria, Cosenza, Crotone, Vibo Valentia), Sicilia (i.e., Palermo, Enna, Messina, Catania, Caltanissetta), Campania (i.e., Napoli and Caserta), Puglia (i.e., Lecce, Taranto) and Sardegna (i.e., Cagliari). Provinces with the lowest unemployment rates are located in Northern and Central Italy, covering regions such as Lombardia (i.e., Lecco, Bergamo, Mantova, Cremona, Como), Veneto (i.e., Vicenza, Treviso, Belluno), Emilia Romagna (i.e., Reggio Emilia, Modena, Bologna), Trentino-Alto Adige (i.e., Bolzano-Bozen), 


\section{Enrico Santarelli, Martin Carree and Ingrid Verheul}

Piemonte (i.e., Biella), Friuli Venezia Giulia (i.e., Pordenone) and Toscana (i.e., Siena). The variation in unemployment in Italy also becomes visible from Figure A.1 in the appendix.

[TABLE 1 about here]

The distribution of unemployment rates in Italy appears to be in line with the 'division' between Southern and Northern/Central regions. However, the official unemployment rate has been decreasing since 1998 and the decrease appears larger for the Southern than for the Center and Northern part of Italy (BANCA D'ITALIA, 2005). It should also be noted that in the Southern regions the shadow economy is larger than elsewhere in the country, possibly resulting into an underestimation of unemployment rates (ISTAT, 2005). According to ISTAT the ratio of irregular to regular jobs varies between 20.9\% (Puglia) and 31.0\% (Calabria) in the large Southern regions; between 7.3\% (Lombardia) and 12.8\% (Friuli Venezia Giulia) in the large Northern regions; and between 8.6\% (Emilia Romagna) and 14.4\% (Lazio) in the large Central regions.

For the entry rates there is more divergence across regions. We see high entry rates in several provinces in Toscana (i.e., Massa, Prato, Livorno), Emilia Romagna (i.e., Reggio Emilia, Rimini), Puglia (i.e., Brindisi, Taranto, Lecce), and in the Northern region of Piemonte (i.e., Novara). Although several of the provinces with high entry rates are characterized by a low value added per capita (e.g., Vibo Valentia, Crotone, Lecce), there are also provinces with low entry rates with a relatively low value added per capita (e.g., Enna, Messina, Caltanissetta). Some of the provinces 'hosting' the major cities in Italy (e.g., Roma and Milano) are characterized by relatively low entry rates. Again, the size of the shadow economy may play a role in explaining regional differences where firms registering with the Chamber(s) of Commerce may already have been active in the informal sector for a long time 


\section{Enrico Santarelli, Martin Carree and Ingrid Verheul}

and can be considered established rather than new firms, with a disproportional high contribution to bringing down unemployment (AUDRETSCH et al., 1999).

It is interesting to see that the 'poorest' provinces in terms of value added per capita, most of which are situated in the Southern part of Italy, are also characterized by the lowest exit rates. Several of the provinces with high entry rates (such as Pescara, Reggio Emilia, Prato, Rimini and Livorno) also denote high exit rates. Conversely, provinces 'hosting' the major cities Roma and Milano, but also the medium-sized city Bolzano, are characterized by relatively low entry and exit rates. The data in Table 1 suggest there is no obvious relationship between unemployment and entry and/or exit rates in Italy. Indeed, as discussed, Bolzano combines a low unemployment rate with relative low entry and exit rates; the province of Messina is characterized by a relatively high unemployment rate and relatively low entry and exit rates; and Reggio Emilia combines a low unemployment rate with high entry and exit rates.

\section{MODEL SPECIFICATION AND SUMMARY STATISTICS}

In this section we introduce our two models. In the first model we do not take into account cross-border effects and concentrate only on individuals - unemployed or employed - starting or closing a business in the province they live in. In the second model we incorporate crossborder effects by allowing for the possibility that firms are started by unemployed individuals from adjacent provinces. Index $i$ represents the province $(i=1, \ldots, 103)$ and index $t$ represents the year $(t=1997, \ldots, 2003)$. Total labor force, i.e., the sum of employed and unemployed individuals, is presented by $L_{i t}$, while the provincial number of unemployed is presented by $U_{i t}$. The unemployment rate $u_{i t}$ equals the ratio $U_{i t} / L_{i t}$. We use symbols $E_{i t}$ and $X_{i t}$ for number of entrants and number of firm exits. The entry and exit rate of firms can be measured either in terms of labor, assuming that one firm represents one self-employed individual (labor market approach), or in terms of number of firms (ecological approach) (ARMINGTON and 


\section{Enrico Santarelli, Martin Carree and Ingrid Verheul}

ACS, 2002). In this paper the entry and exit rates are relative to the total labor force, i.e., entry and exit rates can be presented as follows: $e_{i t}=E_{i t} / L_{i, t-1}$ and $x_{i t}=X_{i t} / L_{i, t-1}{ }^{8}$

In the first model, neglecting cross-border effects, we assume that new firms are started by employed or unemployed individuals from within the own province. The question is whether in regions with high unemployment there is higher (net) entry and lower exit of firms than in regions with low unemployment. To test this we propose the following model, where $Z_{i t}$ refers to a selection of other explanatory variables:

(1) $E_{i t}=a_{t} L_{i, t-1}+b U_{i, t-1}+c Z_{i t}+\varepsilon_{i t}^{E}$

(2) $X_{i t}=d_{t} L_{i, t-1}+e U_{i, t-1}+f Z_{i t}+\varepsilon_{i t}^{X}$

(3) $E_{i t}-X_{i t}=g_{t} L_{i, t-1}+h U_{i, t-1}+j Z_{i t}+\varepsilon_{i t}^{N}$

The first determinant in equation (1), $L_{i t-1}$, is the total labor force in the previous year. For each individual in the labor force, employed or unemployed, there is a probability $a_{t}$ that (s)he starts an enterprise. This probability is made time-dependent because of the relaxation of entry regulation in Italy in the period under consideration. SCHIVARDI and VIVIANO, 2007, discuss the 1998 Bersani Law that reformed the Italian retail trade sector ${ }^{9}$. The second determinant, $U_{i, t-1}$, represents the number of unemployed individuals. There is an additional probability $b$ for the unemployed (over and above $a_{t}$ ) to start a firm. Unemployment has a positive (push) effect on entry if $b>0$, which means that unemployed individuals are more likely to start new firms than employed individuals. Similar interpretations are valid for the exit equation (2) and net entry equation (3). The parameter $e$ will be positive when unemployment serves as a proxy for lack of entrepreneurial opportunities for incumbent business. It will be negative when unemployment results in a lack of job alternatives discouraging self-employed individuals to close down their business. The parameter $h$ is the difference between $b$ and $e$. Equations (1) to (3) are expressed in absolute numbers. A 


\section{Enrico Santarelli, Martin Carree and Ingrid Verheul}

disadvantage of using absolute numbers is that large provinces in terms of population (e.g., Roma and Milano) tend to dominate the analysis. This is why we estimate the equations in relative terms. In relative terms all variables are divided by the labor force in the previous year $\left(L_{i, t-1}\right)$. This leads to the following set of equations to be estimated:

(1a) $e_{i t}=a_{t}+b u_{i, t-1}+c Z_{i t} / L_{i, t-1}+\varepsilon_{i t}^{E}$

(2a) $x_{i t}=d_{t}+e u_{i, t-1}+f Z_{i t} / L_{i, t-1}+\varepsilon_{i t}^{X}$

(3a) $e_{i t}-x_{i t}=g_{t}+h u_{i, t-1}+j Z_{i t} / L_{i, t-1}+\varepsilon_{i t}^{N}$

The following control variables are included in the $Z_{i t} / L_{i, t-1}$-variable:

(i) The variable patents captures the (potential) effect of technological development on new firm formation and is measured by the number of patents in 2003 per 1000 firms (source: Unioncamere). Following ARMINGTON and ACs, 2002, we allow firm entry (and exit) rates to differ between low- and high-tech regions. CHOI and PHAN, 2006, find that patent application per capita is negatively associated to new firm formation in the U.S. They argue that patents are an indicator of venture success rather than a cause of firm formation. However, their research is on nation-wide time-series data and not on regional panel data.

(ii) The variable growth is measured by the relative change in the provincial value added (valore aggiunto a prezzi base - al netto dei SIFIM, source: ISTAT) in the previous period. Most studies at the industry level have found a positive and significant effect of profitability and market growth on both gross and net entry (cf. CARREE and THURIK, 1996). We want to test whether the same effect arises at the provincial level. This variable should correct (together with vapc) for 'pull' effects in the unemployment-entry relationship.

(iii) The variable tourists measures the extent to which the provincial economy benefits from tourism (high in e.g., Firenze and Venezia, source: ISTAT). Regions with high levels of tourism may be characterized by high levels of new firm formation, although new firm 


\section{Enrico Santarelli, Martin Carree and Ingrid Verheul}

formation may diminish when a certain threshold of numbers of visiting tourists is reached. Overexploitation of locally available resources may be a reason for firms to abandon central locations (RUSSO, 2002). Since tourists refers to absolute numbers, in the analysis we divide it by provincial labor force.

(iv) The variable city is a dummy variable with value 1 for the four largest cities in terms of population (Torino, Milano, Napoli and Roma), and 0 otherwise. We control for the possibility that provinces with large Italian metropolitan cities display relatively high entry rates $^{10}$. This is in line with Reilly's Law (REILLY, 1931) positing that the larger the city, the larger the trade area around it. Large metropolitan areas are likely to attract new firms in the surrounding area (FotOPOULOS and LOURY, 2000). Other studies have alluded to the attractiveness of urban areas for new firm formation, including the "inner-city incubator" hypothesis by VERNON, 1960, and the "filtering down" hypothesis by THOMPSON, 1968. REYNOLDS et al., 1994, find that regional population density has a positive effect on the birth rate of firms (per population) in several countries (including Italy).

(v) The presence of industrial districts is captured by the dummy variable inddist with value 1 for provinces with at least one industrial district (Source: Unioncamere) and 0 otherwise. There are 22 provinces with inddist equal to $1 .{ }^{11}$ It is likely that in regions with industrial districts entry rates are higher. An industrial district can be seen as a local production system stimulating new firm formation by an accelerated process of labor division and specialization (BECATTINI, 1990; BRUSCO, 1982). Industrial districts tend to be characterized by many small firms that in turn subcontract production to other small firms (EUROPEAN COMMISSION, 2002, p. 24; SANTARELLI, 2006).

(vi) The variable wage represents the regional (manufacturing) wage level (source: ISTAT). This is the only variable that is not available at the provincial level, but it is available at the aggregate level of the 20 Italian regions. High wage levels are expected to have a 


\section{Enrico Santarelli, Martin Carree and Ingrid Verheul}

negative effect on firm entry and a positive effect on firm exit. High wages imply high opportunity costs for the self-employed and also high wage costs when employing workers. Indeed, ASHCROFT et al., 1991, show that average annual wages per employee has a negative influence on new firm formation at the county level in Great Britain.

(vii) Value added per capita, vapc, is based on provincial value added data. Including this variable controls for the fact that the North, South and Central parts of Italy differ in terms of level of development. Level of development may again be a proxy for a range of related factors and may, as such, be linked to new firm formation.

(viii) The provincial sectoral composition of the firm population is measured by the variable commerce. This variable is constructed as the ratio of the number of registered incumbent firms in the commercial sector (i.e., retail and wholesale) over the number of registered incumbent manufacturing firms. The commercial sector is characterized by the highest number of firms of all sectors (excluding agriculture) and low barriers to entry (GAROFOLI, 1994). We compare the size of this sector to that of manufacturing which, on average, has higher barriers to entry as well as a higher average firm size. This is in line with ASHCROFT et al., 1991, p. 400, who include the ratio of industries with low barriers to those with high barriers as element of their index of entrepreneurial potential.

In the second model we incorporate the possible effects of unemployment in adjacent provinces. ${ }^{12}$ Unemployed individuals in province $i$ may start enterprises in the adjacent province $j$, but also the other way around. This means that we should not only consider the adjacent provinces, but also the provinces adjacent to those (adjacent) provinces. The reason is that unemployed individuals in adjacent province $j$ may not only be attracted towards province $i$ but also to (competing) provinces adjacent to province $j$. Assume that the relative size of a province - with respect to adjacent provinces - determines the probability of a person starting in his/her home province $i$. The relative size can be expressed as $L_{i} /\left(L_{i}+\sum_{j \in A_{i}} L_{j}\right)$ 


\section{Enrico Santarelli, Martin Carree and Ingrid Verheul}

where labor force is taken as size indicator of the province and $A_{i}$ is the set of provinces adjacent to province $i$. Likewise, the probability of a person from adjacent province $j$ to start a firm in province $i$ is determined by the relative size of province $i$ for this adjacent province: $L_{i} /\left(L_{j}+\sum_{k \in A_{j}} L_{k}\right)$ where $i \in A_{j}$. Multiplying this with the number of unemployed $U_{i}$ of the own province and $U_{j}$ of the adjacent provinces results in the following model for entry:

$$
\text { (4) } \begin{aligned}
E_{i t}= & a_{t} L_{i, t-1}+b^{P} \frac{U_{i, t-1} L_{i, t-1}}{L_{i, t-1}+\sum_{j \in A_{i}} L_{j, t-1}}+b^{A P} \sum_{j \in A_{i}} \frac{U_{j, t-1} L_{i, t-1}}{L_{j, t-1}+\sum_{k \in A_{j}} L_{k, t-1}}+c Z_{i t}+\varepsilon_{i t}^{E}= \\
& a_{t} L_{i, t-1}+b^{P} U P_{i, t-1}+b^{A P} U A P_{i, t-1}+c Z_{i t}+\varepsilon_{i t}^{E}
\end{aligned}
$$

The equations for exit, $X_{i t}$, and for net entry, $E_{i t}-X_{i t}$, are again identical:

(5) $X_{i t}=d_{t} L_{i, t-1}+e^{P} U P_{i, t-1}+e^{A P} U A P_{i, t-1}+f Z_{i t}+\varepsilon_{i t}^{X}$

(6) $E_{i t}-X_{i t}=g_{t} L_{i, t-1}+h^{P} U P_{i, t-1}+h^{A P} U A P_{i, t-1}+j Z_{i t}+\varepsilon_{i t}^{N}$

In contrast to the first model, the second model allows for unemployed from within the province to start-up in adjacent provinces and the other way around. Because it is expected that unemployed individuals are more likely to consider starting up a business in the own province than in adjacent provinces, we expect that $b^{P}$ exceeds $b^{A P}$. Similarly, it is expected that $e^{P}$ is larger than $e^{A P}$ and $h^{P}$ is larger than $h^{A P}$. Again, equations (4) to (6) are estimated in relative terms (relative to $L_{i, t-1}$ ), resulting into the following set of equations:

(4a) $e_{i t}=a_{t}+b^{P} U P_{i, t-1} / L_{i, t-1}+b^{A P} U A P_{i, t-1} / L_{i, t-1}+c Z_{i t} / L_{i, t-1}+\varepsilon_{i t}^{E}$

(5a) $x_{i t}=d_{t}+e^{P} U P_{i, t-1} / L_{i, t-1}+e^{A P} U A P_{i, t-1} / L_{i, t-1}+f Z_{i t} / L_{i, t-1}+\varepsilon_{i t}^{X}$ 
(6a) $e_{i t}-x_{i t}=g_{t}+h^{P} U P_{i, t-1} / L_{i, t-1}+h^{A P} U A P_{i, t-1} / L_{i, t-1}+j Z_{i t} / L_{i, t-1}+\varepsilon_{i t}^{N}$

Table 2 presents summary statistics (i.e., mean and standard deviation) for all variables included in the empirical analysis. Entry, exit, net entry and unemployment are presented both in terms of absolute values (i.e., $E, X, E-X$ and $U$ ) and in relative values vis-à-vis the labor force (i.e., $e, x, e-x$ and $u$ ). The controls are given in relative terms (i.e., $Z_{i t} / L_{i, t-1}$ ). There is a relatively strong correlation between the explanatory variables $u_{i, t-1}$ and $v a p c_{i, t-1}$ $(-0.825)$. Unemployment tends to be lower in richer provinces. We decided to include both variables since excluding value added per capita may lead to misinterpretation of the unemployment effect which may be due to wealth differences between provinces.

[TABLE 2 about here]

\section{EMPIRICAL RESULTS}

The results for the equations (1a)-(3a), neglecting the possible influence of unemployment in adjacent provinces, are presented in Table 3. The results for the equations (4a)-(6a) are presented in Table 4. We use the technique of Seemingly Unrelated Regressions for estimating the gross entry and exit equations. This allows for possible correlation between the error terms of these equations, due to omitted variables affecting both entry and exit simultaneously ${ }^{13}$. The top part of Table 3 (y1997 through y2003) shows the year-specific fixed effects. Subsequently, the effect of unemployment is presented (i.e., parameters $b, e$ and h). The bottom part of the table shows the results for the eight other explanatory variables. Table 4 has a similar structure but here the effect of unemployment is divided into ownprovince (P) and adjacent-province (AP) effects. 


\section{Enrico Santarelli, Martin Carree and Ingrid Verheul}

First, we discuss the results of Table 3 . The year-specific effects of entry increase over the years, starting at a low level in 1997 and 1998, and increasing to a higher level in the period after 1999. This time effect can not be observed for exit. Hence, the increased (gross) entry in the period between 1997 and 2003 may be an indication of a range of policy changes in the 1990s. There has been deregulation and the introduction of entry subsidies (mostly soft loans) as reported by, e.g., SANTARELLI and VIVARELLI, 2002. In addition, investment subsidies were granted in disadvantaged areas as specified in Law 488 of 1992 (cf. BARCA and PELLEGRINI, $2002)^{14}$

The degree of unemployment in a province appears to have a negative effect on the rate of new firm formation. This result is in line with REYNOLDS et al., 1994, reporting a negative effect of unemployment on the firm birth rate in Italy. We also see a clear negative effect of unemployment on exit $(X$ or $x)$. Combining the two effects results in a positive overall effect on net entry (significant in Table 4). This effect is not due to a 'push' effect of unemployment on new firm formation in the Italian provinces, but can rather be attributed to the fact that provinces with high unemployment rates ceteris paribus are characterized by low subsequent firm exit rates. Ignoring the effect of unemployment on (gross) exit erroneously would have led us to believe that the positive effect of unemployment on net entry is caused by increased (gross) entry.

With respect to the other variables in the model we find that if there is an effect of the number of patents on entry, it is a negative one. There is some indication that entry and exit are lower in provinces characterized by high rates of patenting. Because most patenting activity is undertaken by a limited number of large firms in specific industries, the variable may not adequately reflect technological opportunities available to (very) small firms (CHOI and PHAN, 2006). Note that the effect of patents on entry and exit fails to be significant. 


\section{Enrico Santarelli, Martin Carree and Ingrid Verheul}

Growth in provincial value added (in the previous period) has the expected positive effect on net entry. There is an (insignificant) positive effect on gross entry and an (insignificant) negative effect on firm exit. In thriving (provincial) economies more firms tend to start or survive. Tourism has no significant effect on gross entry and exit, and net entry. Entry tends to be higher in the four largest cities. The net result of entry and exit is positive, i.e., there is a significant effect of city on net entry. It seems that in the period under consideration there were (still) important agglomeration effects. According to the writings of WILLIAM PETTY, 1683, and following Reilly's Law, large metropolitan areas can be seen as typical attractors of new firms (PRED, 1966; ZHANG and ZHAO, 2004). The economies of specialization and those of labor division, both favoring firm entry, are intrinsically linked with the emergence of cities and the growth of metropolitan areas.

[TABLE 3 about here]

[TABLE 4 about here]

The presence of industrial districts has a significant positive effect on gross and net entry, suggesting that these are fruitful areas for new and small firms. The wage variable has the expected negative effect on firm entry. Surprisingly, it also has a negative effect on exit. Hence, high regional wages appear to have a strong negative effect on firm dynamics (entry and exit combined). However, the net effect is significantly negative. The last two control variables are the provincial value added per capita and the sectoral composition. Rich provinces show more entry and exit with the net effect being negative. As expected we find higher rates of entry and exit in provinces characterized by a high ratio of commercial versus manufacturing activities. The barriers to entry and exit are usually lower in commercial activities than in the manufacturing sector. 


\section{Enrico Santarelli, Martin Carree and Ingrid Verheul}

Table 4 shows that unemployment in adjacent provinces has a smaller effect on firm entry and exit rates than unemployment in the own province. Separating the unemployment effect in own-province and adjacent-province effects results in a significant negative effect of ownprovince unemployment on entry. The other variables in Table 4 show similar effects as those in Table 3. The only exception is the city dummy. The results in Table 4 suggest more gross entry but not more net entry in the four largest cities in Italy. The contribution of incorporating unemployment effects of adjacent provinces to explain entry and exit can be seen by the rise in the adjusted R-squared. It rises from 0.229 to 0.255 for the gross entry rate equation and from 0.167 to 0.224 for the exit equation.

\section{CONCLUSIONS}

This paper investigates the relationship between unemployment and firm entry and exit across Italian provinces. Findings indicate that it is important to take into account the effect of unemployment on firm exit, in addition to that on firm entry, to adequately interpret findings on the relationship between unemployment and the development of the number of firms. Ignoring the effect of unemployment on firm exit may erroneously lead us to interpret the positive effect on net entry as a 'push' effect of unemployment. In fact, we do not find evidence for the 'unemployment push' hypothesis. Rather, it appears that a positive effect on net entry is caused by a negative effect on firm exit, indicating a lack of dynamics in the Italian labor market where individuals are not able or willing to switch between occupations. Nevertheless, the results suggest that there is some room for policy initiatives that help increase firm entry. First, we see an increase in the entry rate in the period 1997-2003, which may be connected to deregulation in that period. Second, regions with industrial districts appear to have more entry (and firm dynamics), suggesting that institutions promoting the development of such districts may enhance (net) entry rates. Third, it appears that the 


\section{Enrico Santarelli, Martin Carree and Ingrid Verheul}

unemployed are less likely to start firms than employees. To the extent that this is not related to lower entrepreneurial abilities, it may suggest that the unemployed are blind to entrepreneurial opportunities in other regions of the country. A policy of stimulating awareness may, at least to some extent, promote labor mobility.

The relatively short panel, used in the present study, does not allow for an adequate study of the inter-temporal dynamics of entry and exit over time (cf. JOHNSON and PARKER, 1996). Also, it may be that the effect of unemployment on the start-up of new firms is dependent on its composition in terms of educational background, gender and age distribution. This possible compositional effect has not been taken into consideration in our study. These can be considered important issues for further research. 


\begin{abstract}
${ }^{*}$ ACKNOWLEDGEMENTS - This paper is the result of a series of visits by Martin Carree and Ingrid Verheul to the Department of Economics of the University of Bologna in 2005 and by Enrico Santarelli to the Department of Applied Economics of Erasmus University Rotterdam and the Department of Organization and Strategy of Maastricht University in 2006 and 2007. Comments from seminar participants at the Max Planck Institute of Economics (Jena, April 2006); the $3^{\text {rd }}$ Hellenic Workshop on Efficiency and Productivity Measurement (Patras, June 2006), and the $33^{\text {rd }}$ Annual Conference of the European Association for Research in Industrial Economics (Amsterdam, August 2006) are gratefully acknowledged. We also want to thank three anonymous referees for their useful suggestions.
\end{abstract}

\title{
NOTES
}

${ }^{1}$ Earlier work on Italy includes studies by AUDRETSCH and VIVARELLI, 1995; 1996; GAROFOLI,1994; and SANTARELli and PiergiovanNI, 1995.

${ }^{2}$ An example is the 1998 Bersani Law deregulating the retail trade sector (SCHIVARDI and VIVIANO, 2007).

${ }^{3}$ Unemployment may also affect those who are not yet officially part of the labor force. DI PIETRO, 2006, finds a negative relation between youth unemployment rates and university dropout rates in Italian regions. Low unemployment rates apparently are an incentive to drop out of university education which is very low-cost and without selection mechanisms in Italy.

${ }^{4}$ One way of coping with the negative effect of unemployment on firm formation is by including business cycle and average income level variables in the model.

${ }^{5}$ AUDRETSCH and JIN, 1994, propose to reconcile these seemingly contradicting relationships.

${ }^{6}$ For an overview of recent developments from the new economic 'geography' approach, see ARMINGTON and ACS, 2002.

${ }^{7}$ Although we are aware that also analysis of inactivity rates by region (cf. FAGGIO and NICKELL, 2005) might prove useful to understand the relationship between employment dynamics and rates of new firm formation, in this paper we focus only on the unemployment issue.

${ }^{8} \mathrm{We}$ also examined the results including entry and exit rates relative to the number of incumbent firms (in the previous period). These results are very similar to those including entry and exit rates relative to total labor force. 


\footnotetext{
${ }^{9}$ Prior to the Bersani Law retail establishments were required to have a permit from the town council. The Bersani Law abolished this permit for smaller firms, which now only have to give notice of their activity. See CARREE and NIJKAMP, 2001, for the estimated effects of a similar deregulation on entry and exit rates in Dutch retailing.

${ }^{10}$ The authors are aware that studies by Garofoli, 1994, and SANTARelli and PiergiovanNi, 1995, found contrasting evidence.

${ }^{11}$ Provinces with at least one important "traditional" (according to the definition used by Unioncamere) industrial district are: Ascoli Piceno (shoes), Arezzo (golden jewelry), Avellino (leather), Bari (footwear), Biella (textiles - wool), Brescia (metal household artifacts and machinery for textile industry), Como (silk), Ferrara (mechanical engineering), Macerata (leather products), Mantova (stockings), Modena (knitwear and biomedical industry and ceramics), Pisa (leather), Pordenone (cutlery)), Prato (textiles), Parma (ham), Pesaro-Urbino (furniture), Pavia (machinery for the footwear industry), Siena (furniture), Treviso (sporting footwear), Vicenza (leather), Verona (furniture) and Viterbo (ceramics). Note that the definition of industrial district used here excludes local systems dominated by "focal" or leading firms occupying strategic and central positions due to their extensive network of customers and suppliers (for a further specification, cf. LAZERSON and LORENZONI, 1999).
}

${ }^{12}$ The number of adjacent provinces in Italy varies between one for Sassari and Trieste to eight for Mantova, Milano and Perugia and even nine for Firenze (Florence). The average number of adjacent provinces is 4.46.

${ }^{13}$ JOHNSON and PARKER, 1996 (p. 684), recommend constructing a VAR-system including lags of firm entries and exits. The short time-series dimension of our panel does not allow for several lags. However, we ran each of our regressions including the one-period lagged entry and exit rates in both the entry and exit equations. The results leave the general conclusions unaltered.

${ }^{14}$ Whereas interpretation of the impact of entry subsidies on entry rates is straightforward (see also DEL MONTE and SCALERA, 2001), the role of regional capital incentives in attracting plants to low income areas is more complex. For a discussion of the latter effect see, for example, FAINI and SCHIANTARELLI, 1987. 


\section{Enrico Santarelli, Martin Carree and Ingrid Verheul}

\section{REFERENCES}

ACs Z. J. and ARMington C. (2004) The impact of geographic differences in human capital on service firm formation rates, Journal of Urban Economics 56, 244-278.

ACs Z. J. and Storey D. J. (2004) Introduction: Entrepreneurship and Economic Development, Regional Studies 38, 871-877.

ARMington C. and ACs Z. J. (2002) The determinants of regional variation in new firm formation, Regional Studies 36, 33-45.

Ashcroft B., Love J. H. and MAlloy E. (1991) New firm formation in the British counties with special reference to Scotland, Regional Studies 25, 395-409.

AudretsCH D. B. and FritsCH M. (1994) The geography of firm births in Germany, Regional Studies 28, 359-365.

Audretsch D. B. and Fritsch M. (1999) The industry component of regional new firm formation processes, Review of Industrial Organization 15, 239-252.

AudRETSCH D. B. and JIN J. (1994) A reconciliation of the unemployment - new firm start-up paradox, Small Business Economics 6, 381-385.

Audretsch D. B. and Vivarelli M. (1995) New-firm formation in Italy: a first report, Economics Letters 48, 77-81.

Audretsch D. B. and Vivarelli M. (1996) Determinants of new-firm start-ups in Italy, Empirica 23, 91-105.

Audretsch D. B., Carree M. A., Stel A. J. VAn, and Thurik A. R. (2005) Does selfemployment reduce unemployment?, Discussion Paper 07-2005 on Entrepreneurship, Growth and Public Policy, Max Planck Institute of Economics, Jena.

Audretsch D. B., Klomp L., SANTARelli E. and ThuriK A. R. (2004) Gibrat's Law: Are the services different?, Review of Industrial Organization 24, 301-324. 


\section{Enrico Santarelli, Martin Carree and Ingrid Verheul}

Audretsch D. B., Santarelli E. and Vivarelli M. (1999) Start-up size and industrial dynamics: Some evidence from Italian manufacturing, International Journal of Industrial Organization 17, 965-983.

BANCA D'ItALIA (2005) Sintesi delle note sull'andamento dell'economia delle regioni italiane nel 2004, Banca d'Italia, Roma.

Barca F. and Pellegrini G. (2002) Policy for territorial competitiveness in Europe: Notes on the 2000-2006 plan for the Italian Mezzogiorno, in DonATo V. (Ed.), Real Effects of Regional Integration in the European Union and the Mercosur: Inter-continental Views on Intra-continental Experiences, pp. 63-88, Editorial de la Università di Bologna en Buenos Aires.

BeCAttini G. (1990) The Marshallian industrial district as a socio-economic notion, in PYKE F., Bechttini G. and Sengenberger D. (Eds.), Industrial Districts and Inter-Firm Cooperation in Italy, ILO, Geneva, 35-71

BRUSCO S. (1982) The Emilian model: productive decentralization and social integration, Cambridge Journal of Economics 6, 167-184.

BuZzELli M. (2005) What explains firm transience in house-building? A regional analysis of Ontario, Canada, 1991 and 1996, Regional Studies 39, 699-712.

CAMPBELl III C. M. (1996) The effects of state and industry economic conditions on new firm entry, Journal of Economics and Business 48, 167-183.

CARreE M. A. (2002) Does unemployment affect the number of establishments? A regional analysis for US states, Regional Studies 36, 389-398.

CARree M. A. (2006) On factors promoting and hindering entry and exit, in PARKER S. (Ed.), The Life Cycle of Entrepreneurial Ventures, Springer, New York, 161-183

Carree M. A. and NiJkamp J. (2001) Deregulation in retailing: the Dutch experience, Journal of Economics and Business 53, 225-235. 
Carree M. A. and Thurik A. R. (1996) Entry and exit in retailing: incentives, barriers, displacement and replacement, Review of Industrial Organization 11, 155-172.

Carree M. A., Stel, A. J. van, Thurik, A. R. and Wennekers S. (2002) Economic development and business ownership: An analysis using data of 23 OECD countries in the period 1976-1996, Small Business Economics 19, 271-290.

CHOI Y. R. and Phan P. H. (2006) The influences of economic and technology policy on the dynamics of new firm formation, Small Business Economics 26, 493-503.

DAVIDSSON P., LindMARK L. and OlOFSSON C. (1994) New firm formation and regional development in Sweden, Regional Studies 28, 395-410.

Del Monte A. and ScAlera D. (2001) The life duration of small firms born within a start-up programme: Evidence from Italy, Regional Studies 35, 11-21.

Di Pietro G. (2006) Regional labour market conditions and university dropout rates: Evidence from Italy, Regional Studies 40, 617-630.

EUROPEAN COMMISSION (2002) Regional Clusters in Europe, Observatory of European SMEs, No. 3, European Commission, Brussels.

Evans D. S. and LEIGHTON L. S. (1990) Small business formation by unemployed and employed workers, Small Business Economics 2, 319-330.

FAGGIO G. and NiCKELL S. (2005) Inactivity among prime age men in the UK, CEP Discussion Paper No. 673., Centre for Economic Performance, London School of Economics.

FAINI R. and SChIANTARELli F. (1987) Incentives and investment decisions: The effectiveness of regional policy, Oxford Economic Papers 39, 516-533.

Foti A. and ViVARelli M. (1994) An econometric test of the self-employment model: the case of Italy, Small Business Economics 6, 81-93. 


\section{Enrico Santarelli, Martin Carree and Ingrid Verheul}

Fotopoulos G. and Louri H. (2000) Location and survival of new entry, Small Business Economics 14, 311-321.

FRITSCH M. and FALCK O. (2003) New firm formation by industry over space and time: a multi-level analysis, DIW Berlin Discussion Paper 322, German Institute for Economic Research, Berlin.

Fritsch M. and Mueller P. (2004) Effects of new business formation on regional development over time, Regional Studies 38, 961-975.

GAROFOLI G. (1994) New firm formation and regional development: the Italian case, Regional Studies 28, 381-393.

GUESNIER B. (1994) Regional variation in new firm formation, Regional Studies 28, 347-358.

HamiLton B. H. (2000) Does entrepreneurship pay? An empirical analysis of the returns to self-employment, Journal of Political Economy 108, 604-631.

ISTAT (2005) La misura dell'occupazione non regolare nelle stime di contabilità nazionale, Conti Nazionali - Statistiche in breve, ISTAT, Roma.

JoHNSON P. and PARKER S. (1996), Spatial variations in the determinants and effects of firm births and deaths, Regional Studies 30, 679-688.

KNight F. H. (1921) Risk, Uncertainty and Profit, Houghton Mifflin, New York.

LAZERSON M. and LORENZONI G. (1999) Resisting organizational inertia: the evolution of industrial districts, Industrial and Corporate Change 3, 361-377.

LEE S. Y., FloRIDA R. and ACS Z. J. (2004) Creativity and entrepreneurship: a regional analysis of new firm formation, Regional Studies 38, 879-891.

LOVE J. H (1996) Entry and exit: a county-level analysis, Applied Economics 28, 441-451.

Oxenfeldt A. (1943) New Firms and Free Enterprise, American Council on Public Affairs, Washington DC. 


\section{Enrico Santarelli, Martin Carree and Ingrid Verheul}

PetTy W. (1683) Another essay on political arithmetics, in Hull C. H. (Ed.), Economic Writings of Sir William Petty, Augustus M. Kelly (Reissued in 1963), New York.

PfeIfFER F. and ReIZE F. (2000) Business start-ups by the unemployed - an econometric analysis based on firm data, Labour Economics 7, 629-663.

PRED A. R. (1966) The Spatial Dynamics of U.S. Urban-Industrial Growth, MIT Press, Cambridge MA.

REILly W. J. (1931) The Law of Retail Gravitation, Knickerbocker Press, New York.

REYNOLDS P. D. (1994) Autonomous firm dynamics and economic growth in the United States: 1986-1990, Regional Studies 28, 429-442.

REYNOLDS P. D., MiLler B. and MAKI W. R. (1995) Explaining regional variation in business births and deaths: US 1976-88, Small Business Economics 7, 389-407.

Reynolds P., Storey D. J. and Westhead P. (1994) Cross-national comparisons of the variation in new firm formation rates, Regional Studies 28, 443-456.

RITSILÄ J. and TERVO H. (2002) Effects of unemployment on new firm formation: micro-level panel data evidence from Finland, Small Business Economics 19, 31-40.

Russo A. P. (2002) The "vicious circle" of tourism development in heritage cities, Annals of Tourism Research 29, 165-182.

SANTARELLI E. (2006) Entrepreneurship, innovation, and the evolution of industrial districts, in E. SAnTARELli (Ed.), Entrepreneurship, Growth, and Innovation: The Dynamics of Firms and Industries, Springer, New York, 165-182

Santarelli E. and Piergiovanni R. (1995) The determinants of firm start-up and entry in Italian producer services, Small Business Economics 7, 221-230.

SANTARelli E. and Vivarelli M. (2002) Is subsidizing entry an optimal policy?, Industrial and Corporate Change 11, 39-52. 


\section{Enrico Santarelli, Martin Carree and Ingrid Verheul}

SCHIVARDi F. and ViVIANO E. (2007) Entry barriers in Italian retail trade, Banca d'Italia Temi di discussione No. 616, Rome.

Storey D. J. (1991) The birth of new firms - Does unemployment matter? A review of the evidence, Small Business Economics 3, 167-178.

SUTARIA V. and Hicks D. A. (2004) New firm formation: dynamics and determinants, Annals of Regional Science 38, 241-262.

TAMBUNAN T. (1992) Economic development and small scale enterprises in Indonesia, Entrepreneurship and Regional Development 4, 85-98.

TAMBUNAN T. (1994) Rural small-scale industries in a developing region: sign of poverty or progress? A case study in Ciomas Subdistrict, West-Java Province, Indonesia, Entrepreneurship and Regional Development 6, 1-13.

THOMPSON W. (1968) Internal and external factors in the development of urban economies, in H.S. Perloff and L. Wingo (eds.), Issues in Urban Economics, Washington DC: The Johns Hopkins Press for Resources for the Future, 43-62.

UNIONCAMERE (2002) Osservatorio Unioncamere sulla demografia delle imprese, Unioncamere, Roma.

VERNON R. R. (1960) Metropolis 1985, Harvard University Press, Cambridge MA.

ZHANG Y. and ZHAO X. (2004) Testing the scale effect predicted by the Fujita-Krugman urbanization model, Journal of Economic Behavior and Organization 55, 207-222.

[FIGURE A.1 about here] 


\section{Table 1. Provincial unemployment and entry and exit rates (average yearly rates)}

\begin{tabular}{|c|c|c|c|c|c|}
\hline Province & $\begin{array}{l}\text { Unemployment } \\
\text { rate (average) }\end{array}$ & Province & $\begin{array}{l}\text { Entry rate } \\
\text { (average) }\end{array}$ & Province & $\begin{array}{l}\text { Exit rate } \\
\text { (average) }\end{array}$ \\
\hline Lecco & 2.20 & Messina & 5.41 & Messina & 4.10 \\
\hline Bolzano-Bozen & 2.23 & Biella & 6.19 & Palermo & 4.37 \\
\hline Vicenza & 2.84 & Bolzano-Bozen & 6.33 & Reggio Calabria & 4.39 \\
\hline Bergamo & 2.93 & Roma & 6.38 & Roma & 4.46 \\
\hline Reggio Emilia & 3.00 & Lodi & 6.52 & Catania & 4.74 \\
\hline Mantova & 3.15 & Sondrio & 6.54 & Nuoro & 4.75 \\
\hline Treviso & 3.16 & Milano & 6.63 & Napoli & 4.80 \\
\hline Modena & 3.31 & Enna & 6.64 & Bolzano-Bozen & 5.01 \\
\hline Cremona & 3.34 & Belluno & 6.70 & Potenza & 5.08 \\
\hline Belluno & 3.49 & Ascoli Piceno & 6.79 & Ragusa & 5.12 \\
\hline Pordenone & 3.62 & Trento & 6.82 & Cosenza & 5.16 \\
\hline Biella & 3.75 & Aosta & 6.92 & Lecce & 5.40 \\
\hline Bologna & 3.84 & Caltanissetta & 6.96 & Sassari & 5.40 \\
\hline Siena & 4.06 & Varese & 6.99 & Salerno & 5.40 \\
\hline Como & 4.11 & Perugia & 7.01 & Milano & 5.42 \\
\hline Taranto & 20.16 & Brindisi & 8.24 & Venezia & 6.81 \\
\hline Lecce & 20.78 & Taranto & 8.33 & Alesssandria & 6.83 \\
\hline Vibo Valentia & 21.03 & Novara & 8.36 & Vercelli & 6.90 \\
\hline Crotone & 21.19 & Crotone & 8.39 & Pescara & 6.93 \\
\hline Caltanissetta & 22.88 & Massa & 8.40 & Gorizia & 6.93 \\
\hline Cagliari & 23.12 & Lecce & 8.42 & Bologna & 6.94 \\
\hline Cosenza & 23.99 & Pescara & 8.45 & Reggio Emilia & 6.95 \\
\hline Catania & 24.28 & Campobasso & 8.54 & La Spezia & 6.96 \\
\hline Caserta & 25.59 & Rovigo & 8.57 & Torino & 7.00 \\
\hline Messina & 25.79 & Prato & 8.60 & Ferrara & 7.04 \\
\hline Catanzaro & 26.20 & Vibo Valentia & 8.60 & Livorno & 7.07 \\
\hline Palermo & 26.63 & Caserta & 8.75 & Udine & 7.08 \\
\hline Napoli & 26.94 & Rimini & 8.79 & Rimini & 7.09 \\
\hline Reggio Calabria & 28.58 & Livorno & 8.84 & Savona & 7.46 \\
\hline Enna & 28.86 & Reggio Emilia & 9.64 & Prato & 7.96 \\
\hline
\end{tabular}


Enrico Santarelli, Martin Carree and Ingrid Verheul

Table 2. Summary statistics

E Variable
$\mathrm{X}$
$\mathrm{E}-\mathrm{X}$
$\mathrm{U}$
$\mathrm{L}$
$\mathrm{e}$
$\mathrm{X}$
$\mathrm{e}-\mathrm{x}$
$\mathrm{u}$
up
uap
patents
growth
tourists
city
vapc
inddist
wage
commerce

Number of entrants
Number of exits

Mean

St.dev.

Net number of entrants

$3143.7 \quad 3778.2$

Number of unemployed

$701.3 \quad 1385.6$

Labor force

Entry rate

Exit rate

Net entry rate

Unemployment rate

Provincial size-weighted u

Adjacent provincial size-weighted u

$24.52 \quad 38.08$

$226.86 \quad 255.01$

$13.97 \quad 3.91$

$\begin{array}{ll}11.09 & 3.28\end{array}$

$\begin{array}{ll}2.88 & 2.67\end{array}$

$0.105 \quad 0.075$

$0.023 \quad 0.031$

$0.084 \quad 0.070$

Number of patents per firm

1.392

Value added growth rate

0.954

0.045

0.025

Relative number of tourists

3.73

Dummy four largest cities

0.039

3.91

Value added per capita

16.86

0.193

Industrial district dummy

4.29

Average wage level

0.214

0.410

Ratio of firms in retail/wholesale versus those in

15.45 manufacturing

2.23

1.65

Notes: Average values are presented for a 7-year period. 
Enrico Santarelli, Martin Carree and Ingrid Verheul

Table 3. Estimation results for entry and exit model (1a)-(3a)

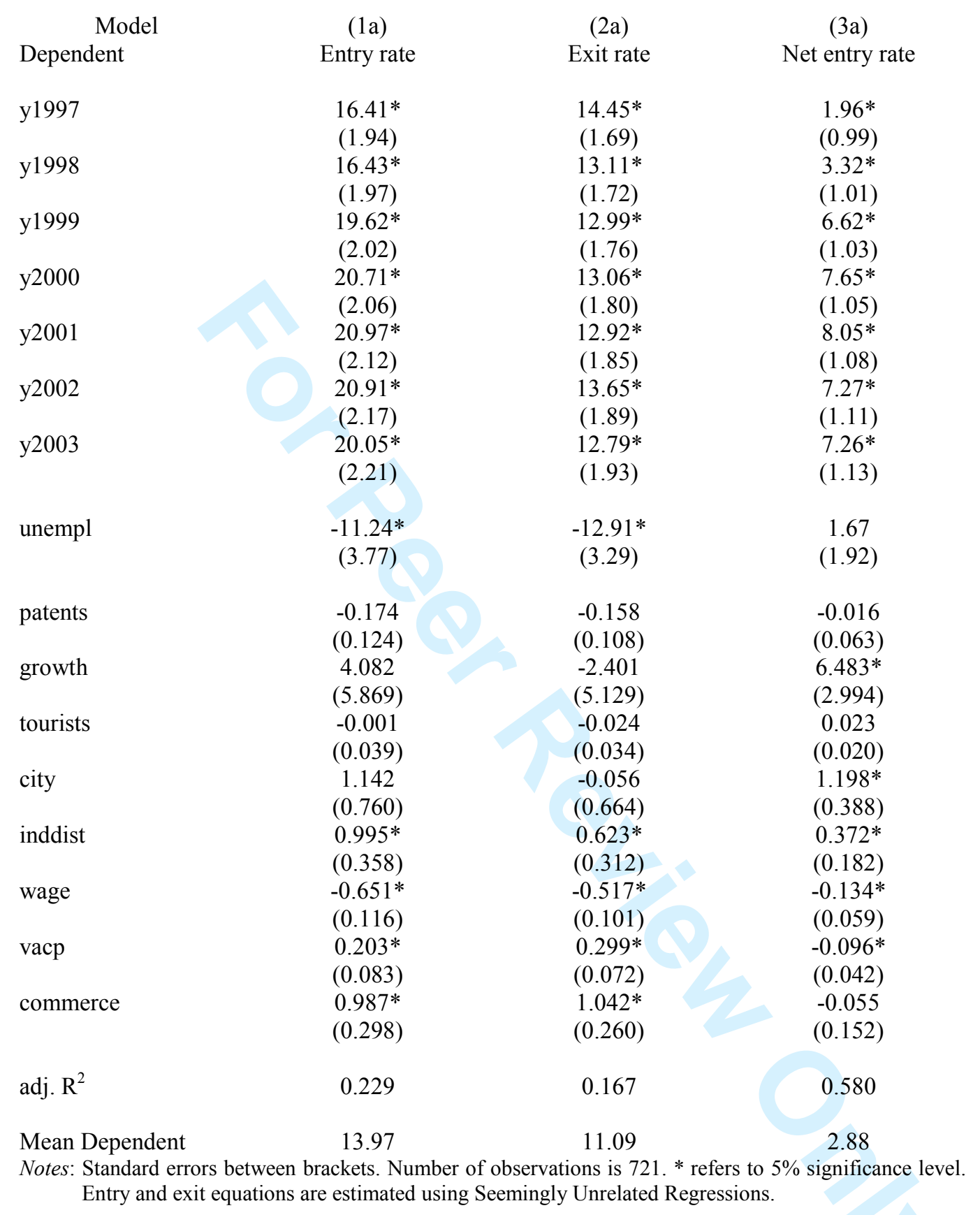


Enrico Santarelli, Martin Carree and Ingrid Verheul

Table 4. Estimation results for entry and exit model (4a)-(6a)

Model

Dependent

y1997

y1998

y1999

y2000

y2001

y2002

y2003

unempl(P)

unempl(AP)

patents

growth

tourists

city

inddist

wage

vacp

commerce

adj. $\mathrm{R}^{2}$

Mean Dependent

13.97 (4a)

Entry rate

$17.80^{*}$

(1.83)

17.94*

(1.85)

$21.19^{*}$

(1.90)

$22.32 *$

(1.93)

$22.56^{*}$

(1.99)

22.50 *

(2.04)

$21.67 *$

(2.08)

$-24.99 *$

(5.73)

$-15.53 *$

(2.88)

$-0.127$

(0.122)

5.921

(5.769)

$-0.024$

(0.039)

$1.647 *$

(0.791)

$1.037 *$

(0.352)

$-0.646^{*}$

(0.115)

0.118

(0.077)

$1.183 *$

(0.288)

0.255 (5a)

Exit rate

$16.21 *$

(1.57)

15.03*

(1.59)

15.01*

(1.63)

$15.12 *$

(1.66)

$14.97 *$

(1.71)

15.71*

(1.75)

14.91*

(1.79)

$-37.57 *$

(4.92)

$-15.45^{*}$

(2.47)

$-0.119$

(0.105)

$-0.132$

(4.947)

$-0.045$

(0.033)

1.134

(0.679)

0.701 *

(0.302)

$-0.550^{*}$

$(0.010)$

$0.211^{*}$

(0.066)

1.350 *

(0.247)

0.224

11.09

(6a)

Net entry rate

1.59

(0.94)

2.91*

(0.95)

6.19*

(0.97)

7.20*

(0.99)

$7.59^{*}$

(1.02)

$6.79 *$

(1.05)

6.76*

(1.07)

12.58*

(2.93)

$-0.08$

(1.47)

$-0.008$

(0.062)

$6.053 *$

(2.953)

0.021

(0.020)

0.513

(0.405)

0.335

(0.180)

$-0.096$

(0.059)

-0.093 *

(0.039)

$-0.166$

(0.147)

0.592

2.88

Notes: Standard errors between brackets. Number of observations is 721 . * refers to $5 \%$ significance level. Entry and exit equations are estimated using Seemingly Unrelated Regressions 
Enrico Santarelli, Martin Carree and Ingrid Verheul

Figure A.1. Unemployment rates in the Italian provinces (2001)

1

2

3

4

5

6

8

9

10

11

12

13

14

15

16

17

18

19

20

21

22

23

24

25

26

27

28

29

30

31

32

33

34

35

36

37

38

39

40

41

42

43

44

45

46

47

48

49

50

51

52

53

54

55

56

57

58

59

60

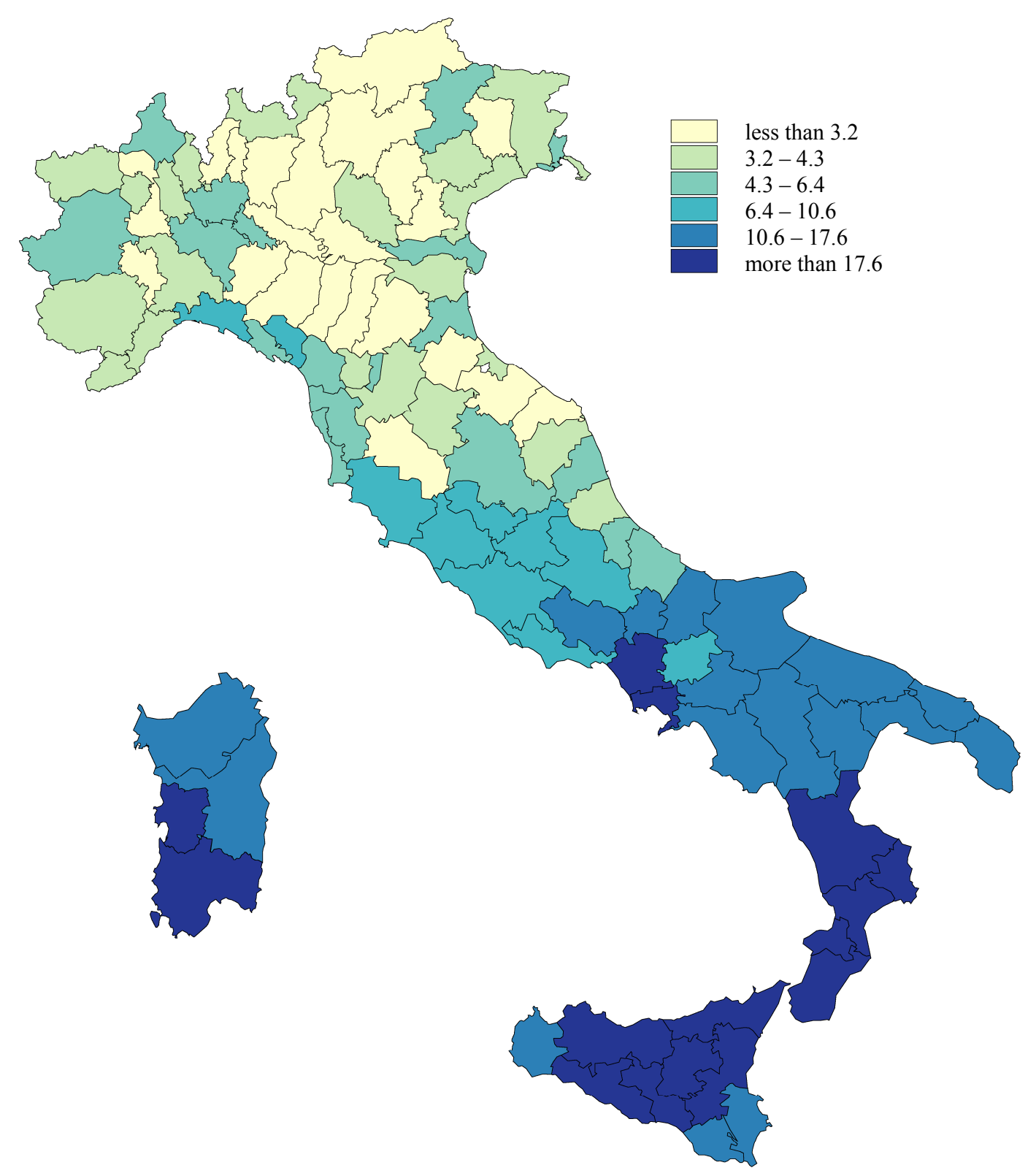

